\title{
A space-time statistical climate model for hurricane intensification in the North Atlantic basin
}

\author{
Erik Fraza, James B. Elsner, and Thomas H. Jagger \\ Department of Geography, Florida State University, 113 Collegiate Way, Tallahassee, FL 32306, USA \\ Correspondence to: Erik Fraza (ef10c@my.fsu.edu)
}

Received: 4 November 2015 - Revised: 20 June 2016 - Accepted: 8 July 2016 - Published: 2 August 2016

\begin{abstract}
Climate influences on hurricane intensification are investigated by averaging hourly intensification rates over the period 1975-2014 in $8^{\circ} \times 8^{\circ}$ latitude-longitude grid cells. The statistical effects of hurricane intensity and sea-surface temperature (SST), along with the climatic effects of El Niño-Southern Oscillation (ENSO), the North Atlantic Oscillation (NAO) and the Madden-Julian Oscillation (MJO), are quantified using a Bayesian hierarchical model fit to the averaged data. As expected, stronger hurricanes tend to have higher intensification rates, especially over the warmest waters. Of the three climate variables considered, the NAO has the largest effect on intensification rates after controlling for intensity and SST. The model shows an average increase in intensification rates of $0.18[0.06,0.31] \mathrm{m} \mathrm{s}^{-1} \mathrm{~h}^{-1}$ (95\% credible interval) for every 1 standard deviation decrease in the NAO index. Weak trade winds associated with the negative phase of the NAO might result in less vertical wind shear and thus higher mean intensification rates.
\end{abstract}

\section{Introduction}

Hurricanes are powerful warm-core cyclones that are some of the most destructive natural hazards on the planet (NHC, 2013; Peduzzi et al., 2012; Pielke Jr. et al., 2008). Hurricane intensity is estimated by the highest sustained near-surface wind speed within the storm. While the skill of predicting hurricane tracks has improved over the past 20 to 30 years, skill in predicting intensity has lagged considerably behind (e.g., Elsberry et al., 2007, 2013). Specifically, predicting intensity change is difficult with present-day numerical models owing to unresolved small-scale processes including nonhydrostatic thermodynamics.

Hurricane intensification (increasing intensity change) is a well-studied problem in meteorology with particular focus on rapid intensification (RI). RI is defined as a large increase in intensity (e.g., $15 \mathrm{~m} \mathrm{~s}^{-1}$ or $30 \mathrm{kt}$ ) over a limited period of time (e.g., 24 h) (see Kaplan and DeMaria, 2003). Operationally the probability of RI for a particular hurricane is assessed using sea-surface temperature (SST) or ocean heat content (OHC), along with other factors, in a regression model (e.g., DeMaria et al., 1993; Kaplan and DeMaria, 2003; Law and Hobgood, 2007).
Aggregate cases of RI have been studied from a climate perspective. In particular, Klotzbach (2012) finds the number of RI cases in the North Atlantic is about 3 times as high during La Niña than during El Niño with the difference being even larger when cases are restricted to hurricanes in the main development region (MDR). According to Klotzbach (2012) the large-scale mode of tropical variability known as the Madden-Julian Oscillation (MJO, Madden and Julian, 1972) might also play a role. Klotzbach (2012) found twothirds of all RI cases occur in just three of the eight MJO phases.

Much less work has been done to understand intensification spatially. Fraza and Elsner (2015) find a significant relationship between proximate SST and mean intensification. They divide the North Atlantic basin into $4^{\circ}$ latitudelongitude cells and use mean intensification (increasing intensity) as the response variable in a generalized linear regression model with a term for the spatial autocorrelation. The covariates in the model include intensity and SST. Values within the cells are averaged over the entire period of record. By statistically controlling for intensity, the effect of SST on intensification is clearly demonstrated. 
The finding contrasts with results from an earlier study (Balling and Cerveny, 2006) that used current and preceding month's SST in a bivariate correlation analysis.

The present work builds on Fraza and Elsner (2015) by adding climate factors, like El Niño-Southern Oscillation (ENSO), to the model. The climate factors vary with time so the spatial model is extended to include a time-varying component. The purpose of this article is to demonstrate the space-time model and to determine the effect of the climate factors on hurricane intensification controlling for intensity and SST.

The paper is outlined as follows. In Sect. 2 we describe the data that will be used in the model, including the HURDAT2 dataset, climate data, and spatial aggregation of the data. In Sect. 3 we explore the spatial distribution of intensification, intensity, and SST. In Sect. 4 we present the spacetime statistical model and discuss its components. In Sect. 5 we present the results from fitting the model to the data. In Sect. 6 we explore the relationship between intensification and the North Atlantic Oscillation (NAO). In Sect. 7 we discuss our findings, and in Sect. 8 we provide a summary of the paper.

\section{Data}

\subsection{Sources and description}

\subsubsection{Hurricane tracks}

The hurricane data used in this study are derived from the HURDAT2 (Jarvinen et al., 1984). HURDAT2 is a dataset compiled by the National Hurricane Center (NHC) of the National Oceanic and Atmospheric Administration (NOAA). The dataset includes information such as storm center fix (in tenths of degrees), storm intensity, and if the storm center is over land. Storm intensity is measured as the 1 min nearsurface wind speed $(\sim 10 \mathrm{~m})$. The wind speed is provided in knots $\left(1 \mathrm{kt}=0.5144 \mathrm{~m} \mathrm{~s}^{-1}\right)$. Values of these variables are given every $6 \mathrm{~h}$ (00:00, 06:00, 12:00, 18:00 UTC). We use data from the 1975-2014 hurricane seasons. The dataset was downloaded from www.nhc.noaa.gov/pastall.shtml\#hurdat.

\subsubsection{Sea-surface temperatures}

The SST data used in this study are from the NOAA Extended Reconstructed Sea Surface Temperature V3b. The dataset is originally from the International Comprehensive Ocean-Atmosphere Data Set (ICOADS). Statistical methods were used to fill in missing data. The dataset is on a $2^{\circ} \times 2^{\circ}$ global oceanic grid. The dataset was downloaded from http://www.esrl.noaa.gov/psd/data/ gridded/data.noaa.ersst.html\#detail.

Adv. Stat. Clim. Meteorol. Oceanogr., 2, 105-114, 2016

\subsubsection{Climate variables}

The climate variables used in this study are ENSO, NAO, and MJO. We use the Multivariate ENSO Index (MEI) to represent ENSO in our model. The MEI is considered more comprehensive than other common ENSO indices such as Niño 3.4 because the MEI is based on more factors than just an SST index (Klotzbach and Oliver, 2015). The MEI includes six observed variables: sea-level pressure, zonal and meridional components of the surface wind, surface air and sea-surface temperatures, and total cloudiness fraction of the sky.

We use the NAO Index (NAOI) from the Climate Prediction Center (CPC) of NOAA to represent NAO in our model. The index is defined by projecting the 00:00 UTC $500 \mathrm{mb}$ height anomalies for the Northern Hemisphere onto the loading pattern of the NAO (Wallace and Gutzler, 1981). This creates a daily NAOI, which is then converted to a monthly average.

We use the MJO index (MJOI) from Wheeler and Hendon (2004) to represent MJO in our model. The index is defined by extracting the first two empirical orthogonal functions of the combination of the combined fields including 200 and $850 \mathrm{mb}$ zonal wind fields, along with outgoing long-wave radiation. The annual mean and ENSO-type variability were then removed. Finally, the time series is normalized to have a standard deviation of 1 over the time period 1979-2001.

\subsection{Filtering, interpolation, and aggregation}

\subsubsection{Interpolation of hurricane track data}

The $6 \mathrm{~h}$ intervals in HURDAT2 are too coarse for our spatial interpolation. A storm with a forward speed of $10 \mathrm{~m} \mathrm{~s}^{-1}$ will travel $216 \mathrm{~km}$ in $6 \mathrm{~h}$. A storm could pass through a corner of a cell and not get counted in that time. Therefore, we interpolate the hurricane track data to $1 \mathrm{~h}$ intervals using a spline technique. This determines the storm center fix using spherical geometry. Further, the spline interpolation preserves the $6 \mathrm{~h}$ data. This is done by using a piecewise polynomial to determine the values between the preserved $6 \mathrm{~h}$ data. Additional details concerning the interpolation process can be found in Elsner and Jagger (2013).

The intensity change of the storm is computed as the first derivative of the intensity using a Savitzky-Golay smoothing filter and a weighted differencing scheme (Elsner and Jagger, 2013). This technique keeps the minimum and maximum intensities of a storm. This limits the size of the computational errors relative to a simple finite-difference scheme.

\subsubsection{Spatial aggregation of tracks and SST data}

As a compromise between having enough cells and enough data within each cell, we choose an $8^{\circ}$ latitude-longitude grid for the area $10-50^{\circ} \mathrm{N}$ by $20-100^{\circ} \mathrm{W}$. This is done using the raster package in the $\mathrm{R}$ programming language (Hijmans, 


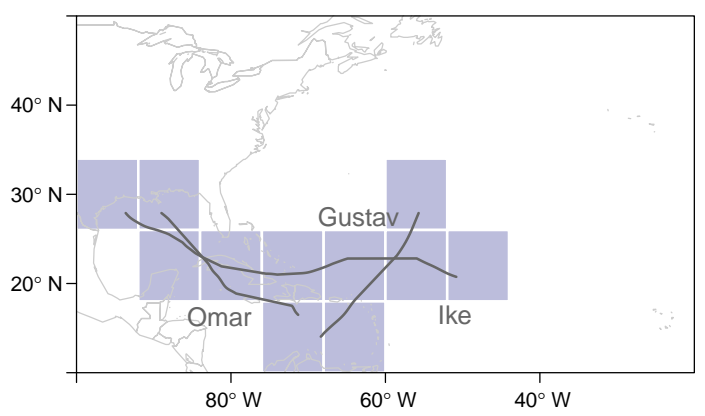

Figure 1. Tracks and corresponding cells for three 2008 hurricanes: Gustav, Ike, and Omar. Each colored cell indicates at least one storm intensifies within its boundaries.

(a)

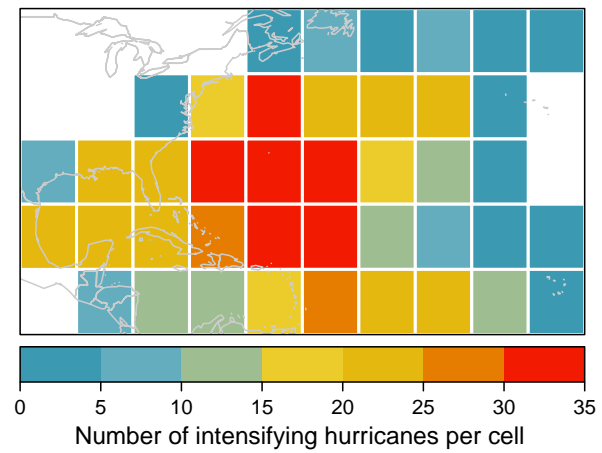

(b)

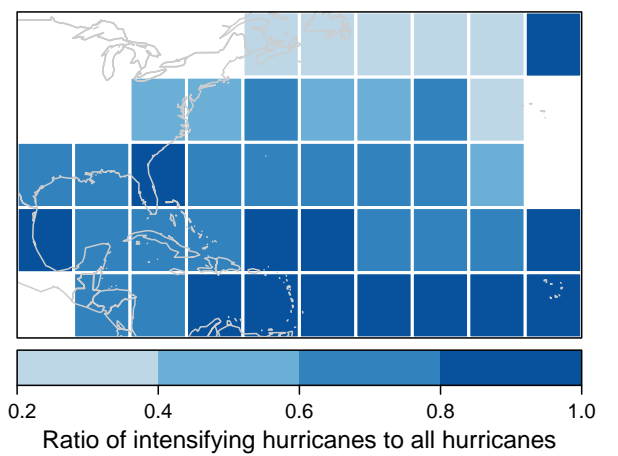

Figure 2. Hurricane intensification count and ratio per cell. (a) Number of intensifying hurricanes per cell, and (b) ratio of total number of hurricanes with at least $1 \mathrm{~h}$ of intensification to total number of hurricanes per cell. The data are from the period 19752014.

2014). An example of our raster grid is shown in Fig. 1. The tracks of three storms from the 2008 Atlantic hurricane season are plotted (Gustav, Ike, and Omar). The tracks represent the paths of each storm when they were at hurricane intensity. Only cells that have at least one center fix of a hurricane intensifying are colored. Annual mean intensity and intensification values are computed for each cell using all center fixes within the cell. The mean intensity and intensification values are calculated per cell per storm, then averaged for each (a)

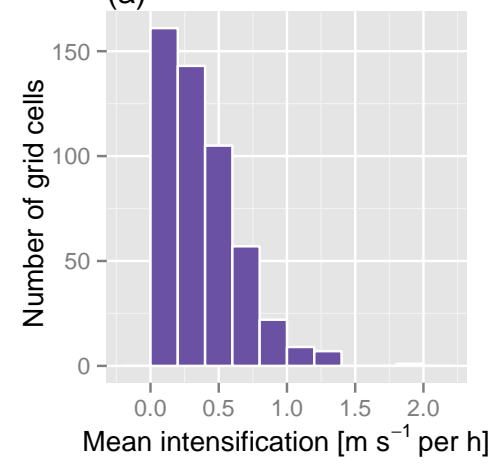

(b)

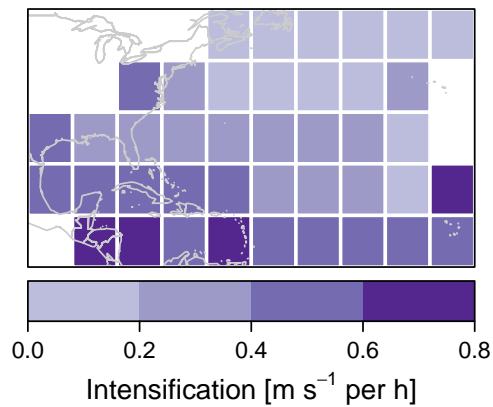

Figure 3. Mean intensification histogram and spatial plot. (a) Histogram of mean hourly intensification in $0.2 \mathrm{~m} \mathrm{~s}^{-1} \mathrm{~h}^{-1}$ intervals, and (b) spatial distribution of mean intensification. The data are for the months June-October over the period 1975-2014.

year. Annual refers to the hurricane season months from June through October. The grid creates a total of $S=50$ cells per year. However, nine cells within the grid do not have a hurricane intensify within its boundaries during our time of interest. These nine cells are therefore removed, leaving $S=41$ cells per year.

\subsubsection{Time filtering of the climate indexes}

We average the monthly MEI values from June through October to get a yearly value and average the monthly NAOI values from January through March to get a yearly value. We also sum the first two principal components of the monthly MJOI from June through October and average the values to get a yearly value.

\section{Exploratory analysis}

Hurricane intensification is most common over the western North Atlantic (Fig. 2). This is also where hurricanes are most frequent. The Gulf of Mexico and northwestern Caribbean Sea are also regions where intensification is relatively more common. Fewer cases of intensification are noted in the southern Caribbean and eastern portions of the basin. 


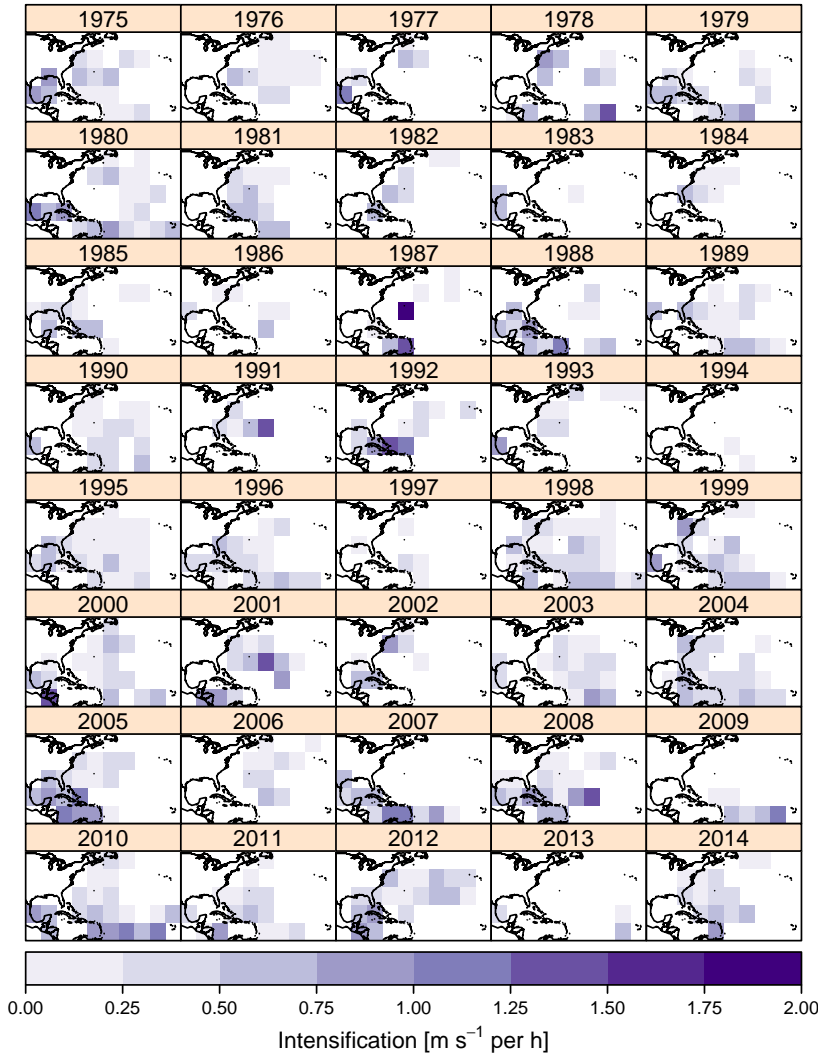

Figure 4. Yearly mean intensification rates for intensifying hurricanes. Mean intensification is calculated over the period JuneOctober for each year 1975-2014.

The ratio of intensifying hurricanes to all hurricanes is highest in the central and eastern MDR. The ratio is lower in most of the Caribbean Sea, as well as the Gulf of Mexico. The ratio is also lower moving north in the basin. The ratios range from 0.2 in the far north of the basin to 1 in the far south and east of the basin.

\subsection{Intensification}

A histogram of basin-wide mean intensification appears to show a gamma distribution (Fig. 3). Intensification is binned at $0.2 \mathrm{~m} \mathrm{~s}^{-1} \mathrm{~h}^{-1}$ intervals starting from no intensification. The largest bins are found closest to zero and decrease moving away from zero. Overall, a total 10312 cells intensify from 232 storms over the time frame. The mean intensification rate is $0.43 \mathrm{~m} \mathrm{~s}^{-1} \mathrm{~h}^{-1}$. The median value is $0.375 \mathrm{~m} \mathrm{~s}^{-1} \mathrm{~h}^{-1}$ with first and third quartiles of 0.140 and $0.613 \mathrm{~m} \mathrm{~s}^{-1} \mathrm{~h}^{-1}$ respectively. This equates to $20.1[6.5,28.6]$ knots day $^{-1}$.

From year to year, the highest mean intensification rates are found in the southern portion of the basin (Fig. 4). There is a wide range in the number of cells that have an intensifying hurricane each year. For instance, only two cells had an intensifying hurricane in 1994. At the other extreme, 1998

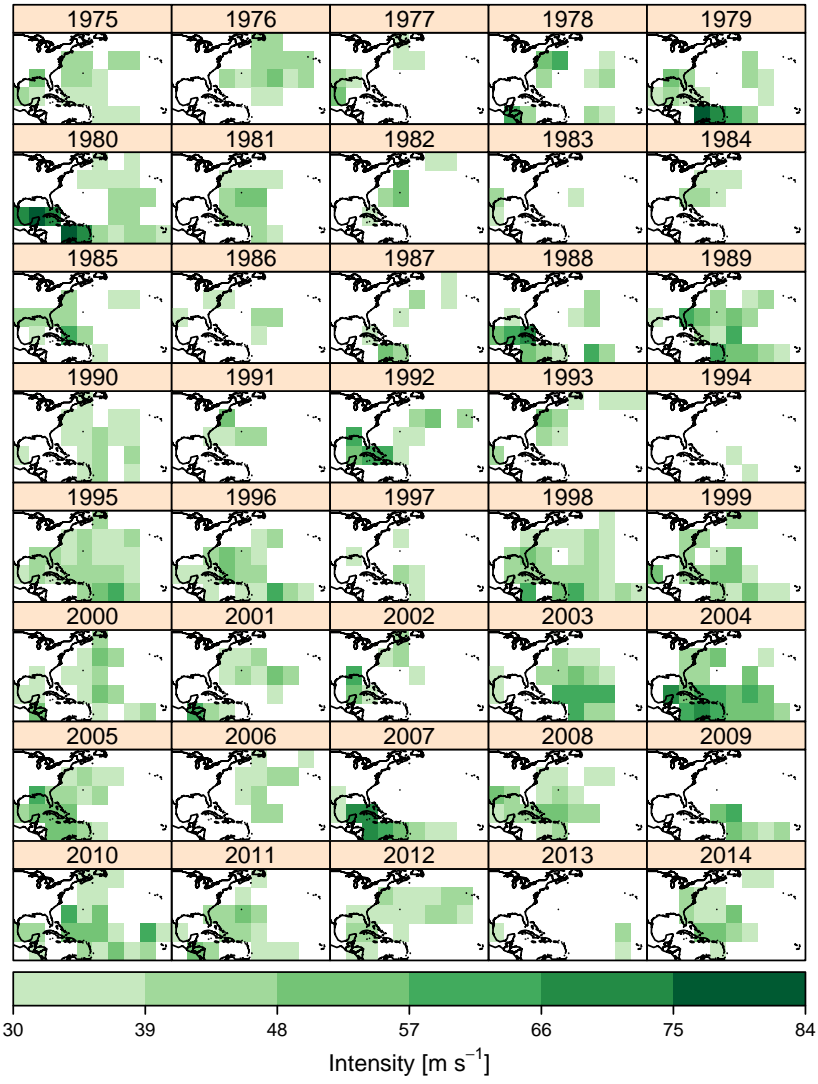

Figure 5. Yearly mean intensity for intensifying hurricanes. Mean intensity is calculated over the period June-October for each year 1975-2014.

had 27 cells with an intensifying hurricane, followed by 1995 ( 25 cells) and 2010 ( 23 cells). The highest mean intensification rate is $1.83 \mathrm{~m} \mathrm{~s}^{-1} \mathrm{~h}^{-1}$ in 1987. The next highest rate is $1.37 \mathrm{~m} \mathrm{~s}^{-1} \mathrm{~h}^{-1}$ in 1978 . Other years with mean intensification rates over $1.25 \mathrm{~m} \mathrm{~s}^{-1} \mathrm{~h}^{-1}$ include 1991, 1992, 2000, 2001, and 2008.

\subsection{Intensity}

From year to year, the highest mean intensities are found in the southern and central portions of the basin (Fig. 5). The highest mean intensity is $77 \mathrm{~m} \mathrm{~s}^{-1}$ in 1980 . Other years with mean intensities over $70 \mathrm{~m} \mathrm{~s}^{-1}$ include 1979 and 2007.

\subsection{Sea-surface temperature}

From year to year, there are no great changes in sea-surface temperature anomalies (Fig. 6). A majority of the negative SST anomalies are found in the early half of the time period, and a majority of the positive SST anomalies are found in the latter half of the time period. All cells with a mean SST $<20^{\circ} \mathrm{C}$ are shown without an SST as these waters are of less interest. 


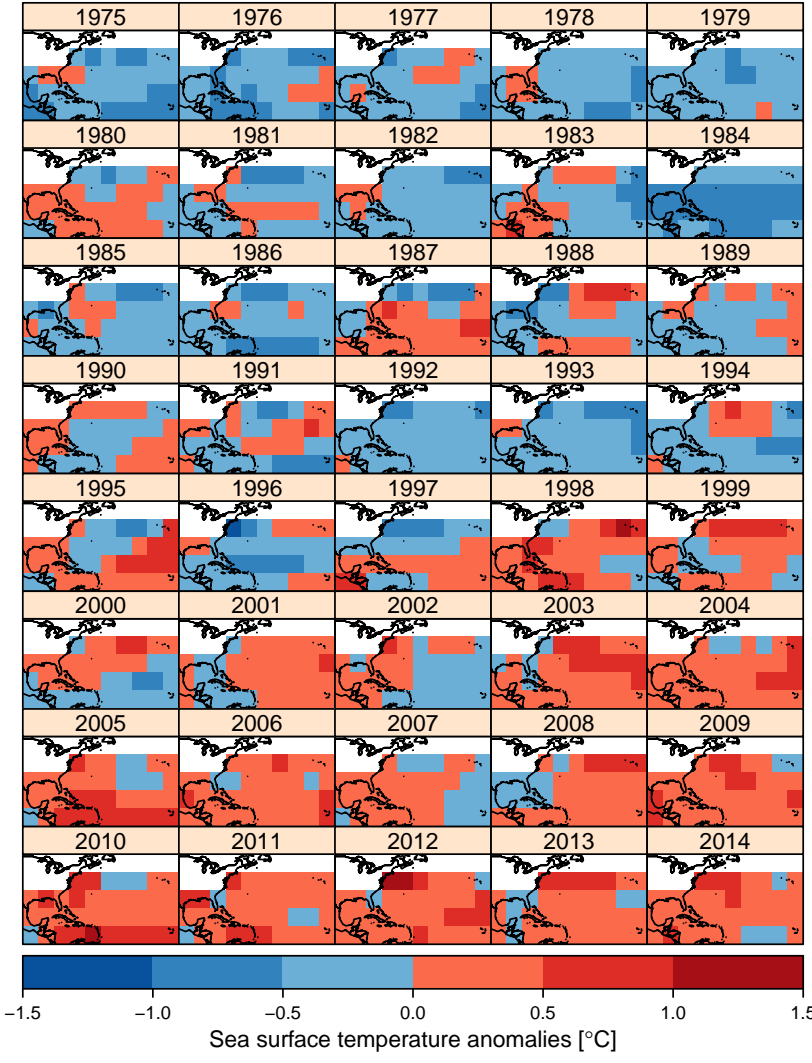

Figure 6. Yearly mean SST anomalies. Mean SST values are calculated over the period June-October for each year 1975-2014. Yearly mean SSTs $<20^{\circ} \mathrm{C}$ are omitted from being plotted.

\subsection{Temporal factors}

The temporal evolution of the MEI shows the strongest El Niño and La Niña events (Fig. 7). Standard deviation values above 0.75 indicate an El Niño event, and values below -0.75 indicate a La Niña event. The extreme years of 1982 1983 and 1997-1998 saw MEI values exceed 1.5 standard deviations (SD).

The temporal evolution of the NAOI varies year to year, but there is no long-term trend. The extreme years of 1989 and 1995 saw NAOI values exceed 1 SD. The temporal evolution of the MJOI varies from year to year but also shows no long-term trend. The extreme years of 1999 and 2010 saw MJOI values below $-0.4 \mathrm{SD}$. Due to incomplete outgoing long-wave radiation observations, 1978 is missing from the MJOI.

\section{Space-time model}

We are interested in the relationship between hurricane intensification and factors that affect it on the climate scale. Our approach is similar to the approach used in Hodges et al. (2014), who examined factors influencing hurricane frequency. We use a full probability model that can account for (a)

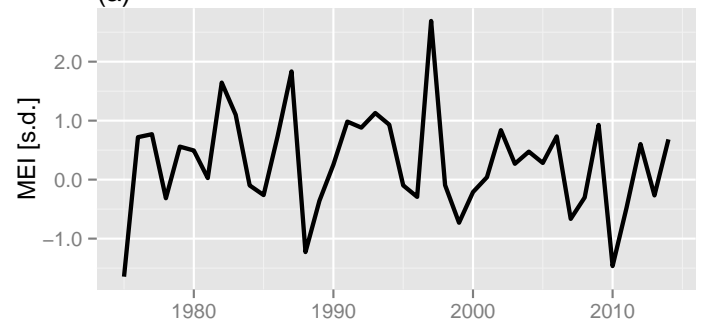

(b)

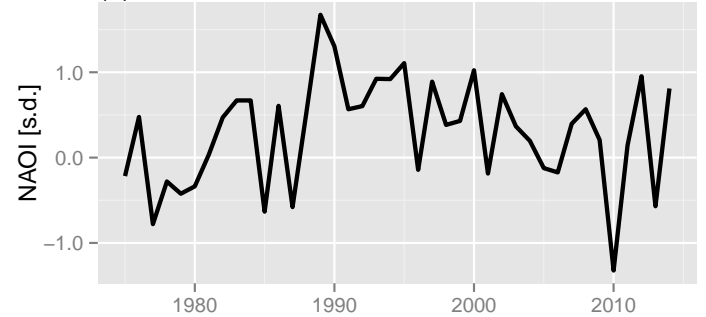

(d)

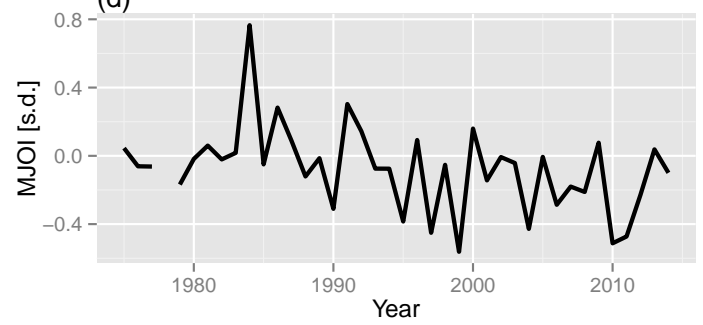

Figure 7. Time series of (a) monthly average of MEI from 1975 to 2014, (b) monthly average of NAOI from 1975 to 2014, and (c) monthly average of MJOI from 1975 to 2014. Due to missing outgoing long-wave radiation data, 1979 is missing from the MJOI

the marginal contributions of each of the climate effects on intensification as well as spatial autocorrelation in intensification values.

The mean intensification in each space-time cell is described by a gamma random variable:

$X_{\mathrm{s}, \mathrm{t}} \mid \alpha_{\mathrm{s}, \mathrm{t}}, \theta_{\mathrm{s}, \mathrm{t}} \sim$ ind gamma $\left(\alpha_{\mathrm{s}, \mathrm{t}}, \theta_{\mathrm{s}, \mathrm{t}}\right) ; \alpha_{\mathrm{s}, \mathrm{t}}>0, \theta_{\mathrm{s}, \mathrm{t}}>0$,

which represents hurricane intensification for each cell for each year from 1975 through 2014. The mean of $X_{\mathrm{s}, \mathrm{t}}$ is represented by $\mu_{\mathrm{s}, \mathrm{t}}=\alpha_{\mathrm{s}, \mathrm{t}} / \theta_{\mathrm{s}, \mathrm{t}}$, which are the shape and rate parameters. Normally in the literature, $\beta$ is used to represent the rate parameter in the gamma distribution. However, to avoid confusion later with the covariates, $\theta$ is used to represent the rate parameter in the gamma distribution.

Adv. Stat. Clim. Meteorol. Oceanogr., 2, 105-114, 2016 
(a)

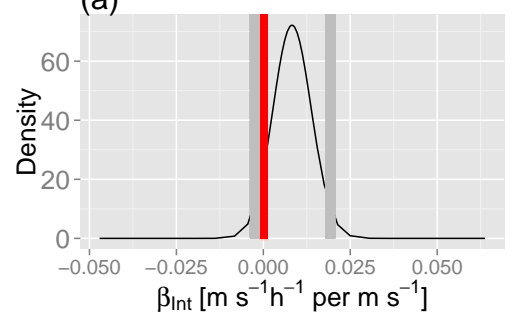

(b)

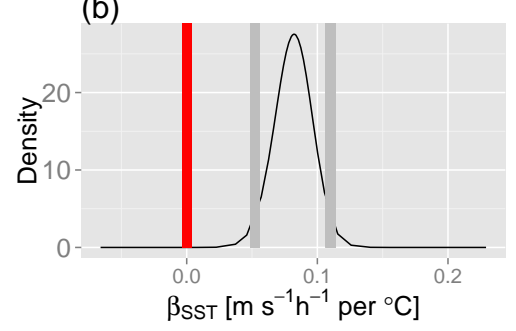

Figure 8. Posterior densities, with all other $\beta$ terms held constant. (a) Modeled density of mean intensification changes per $1 \mathrm{~m} \mathrm{~s}^{-1}$ increase in mean intensity. (b) Modeled density of mean intensification changes per $1^{\circ} \mathrm{C}$ increase in mean SST. The red line represents the $x=0$ line (i.e., no effect). The gray lines represent the $95 \% \mathrm{CI}$.

The log of the mean is modeled as a linear combination of the predictors

$$
\begin{aligned}
\log \left(\mu_{\mathrm{s}, \mathrm{t}}\right)= & \beta_{\mathrm{Int}}(s) \cdot \operatorname{Int}_{\mathrm{s}, \mathrm{t}}+\beta_{\mathrm{SST}}(s) \cdot \mathrm{SST}_{\mathrm{s}, \mathrm{t}} \\
& +\beta_{\mathrm{ENSO}} \cdot \mathrm{ENSO}_{\mathrm{t}}+\beta_{\mathrm{NAO}} \cdot \mathrm{NAO}_{\mathrm{t}} \\
& +\beta_{\mathrm{MJO}} \cdot \mathrm{MJO}_{\mathrm{t}}+u_{\mathrm{s}}
\end{aligned}
$$

where Int $_{\mathrm{s}, \mathrm{t}}$ and $\mathrm{SST}_{\mathrm{s}, \mathrm{t}}$ are the actual intensity and SST values that vary by cell and time. $u_{\mathrm{s}}$ is a spatially dependent Gaussian Markov random field model (Besag, 1975) such that

$u_{i} \mid u_{j}, i \neq j, \tau \sim \operatorname{Gau}\left(\frac{1}{m_{i}} \sum_{i \sim j} u_{j}, \frac{1}{m_{i}} \tau\right)$,

where $m_{i}$ is the number of neighboring cells of location $i$, and $i \sim j$ indicates that $i$ and $j$ are neighbors. The $\beta$ parameters have a log-gamma prior distribution.

The spatially varying $\beta$ parameters are assumed to be the sum of structured and unstructured random effects. The structured effects are described by a Markov random field model (Besag, 1975) and the unstructured effects by a multivariate normal distribution. Additional information concerning the model is available in Hodges et al. (2014), including Eqs. (1)-(5). Specifics about these types of space-time models are available in Cressie and Wikle (2011), especially in chap. 7.

The model is fit using the method of integrated nested Laplace approximation (INLA). INLA is a deterministic technique for Bayesian inference (Blangiardo and Cameletti, 2015) and is available in the inla package for $\mathrm{R}$ (Martins (a)

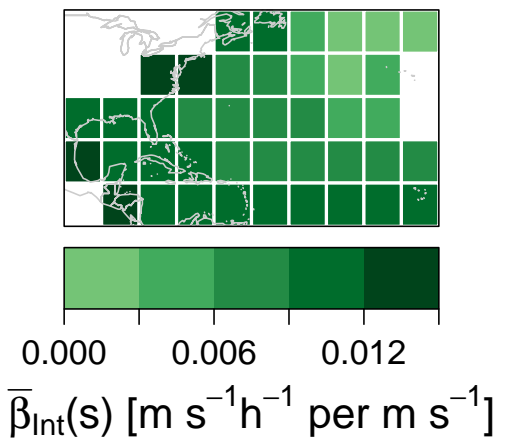

(b)
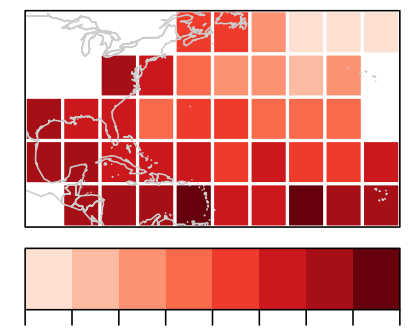

0.0770 .0790 .0810 .0830 .085

$\bar{\beta}_{\text {SST }}(\mathrm{s})\left[\mathrm{m} \mathrm{s}^{-1} \mathrm{~h}^{-1}\right.$ per $\left.{ }^{\circ} \mathrm{C}\right]$

Figure 9. Mean of the posterior densities represented spatially. (a) Mean intensification rate per $1 \mathrm{~m} \mathrm{~s}^{-1}$ increase in intensity. (b) Mean intensification rate per $1^{\circ} \mathrm{C}$ increase in SST.

et al., 2013). Unless otherwise stated, the default options within the inla package are used.

Temporal dependence is very unlikely to be an issue in our model. Given the yearly nature of the measurements, any temporal dependence is very likely to be over a short amount of time and averaged into the yearly climate data.

\section{Results}

Results are presented in the form of posterior densities for the model coefficients. First the intensity and SST model coefficients are investigated (Fig. 8). The model results confirm the significant positive relationship between intensity and intensification shown in Fraza and Elsner (2014). Regions with stronger hurricanes tend to have higher intensification rates. On average across the basin and for this spatial scale for every $1 \mathrm{~m} \mathrm{~s}^{-1}$ increase in intensity, intensification rates increase by $0.0083 \mathrm{~m} \mathrm{~s}^{-1} \mathrm{~h}^{-1}[-0.0025,0.019]$ (95\% credible interval $(\mathrm{CI})$ ).

The model also confirms a significant positive relationship between local SST and intensification as shown in Fraza and Elsner (2015). Warmer ocean regions tend to be those that support higher intensification rates. On average across the basin and on this spatial scale for every $1{ }^{\circ} \mathrm{C}$ warming, in- 
(a)

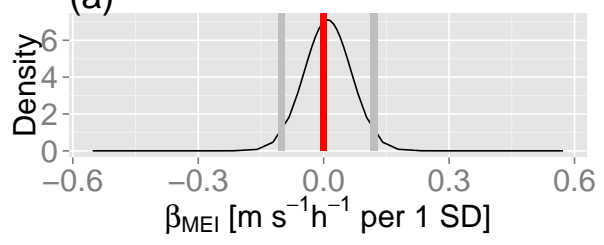

(b)

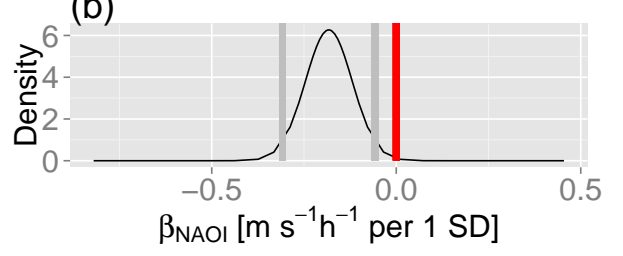

(c)

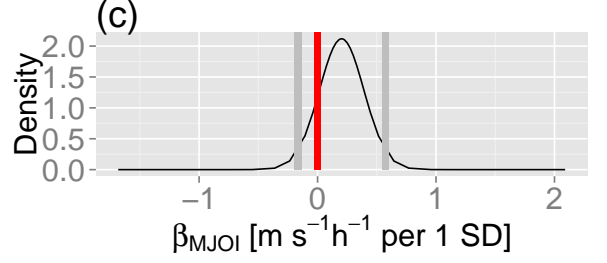

Figure 10. Posterior densities of the climate coefficients from the model. (a) $\beta_{\mathrm{MEI}}$, (b) $\beta_{\mathrm{NAOI}}$, and (c) $\beta_{\mathrm{MJOI}}$. Units are expressed as a change in intensification $\left(\mathrm{m} \mathrm{s}^{-1} \mathrm{~h}^{-1}\right)$ for a 1 standard deviation (SD) change in the covariate. The red line represents the $x=0$ line (i.e., no effect). The gray lines represent the $95 \%$ CI.

tensification rates increase by $0.08 \mathrm{~m} \mathrm{~s}^{-1} \mathrm{~h}^{-1}[0.052,0.11]$ $(95 \% \mathrm{CI})\left(3.7 \mathrm{kt} \mathrm{day}^{-1}\right)$. This means that intensification rates will increase by $21.6 \%$ for every $1{ }^{\circ} \mathrm{C}$ warming. This is comparable to Fraza and Elsner (2015), who found a $16 \%$ increase in intensification rates for every $1{ }^{\circ} \mathrm{C}$ warming. The difference between the increases is likely due to the different spatial scales used.

The magnitude of intensification response to intensity and SST varies spatially (Fig. 9). Posterior density values of intensity range from $0.0012 \mathrm{~m} \mathrm{~s}^{-1} \mathrm{~h}^{-1}$ per m s${ }^{-1}$ in the northern part of the basin to $0.014 \mathrm{~m} \mathrm{~s}^{-1} \mathrm{~h}^{-1}$ per m s $\mathrm{s}^{-1}$ in the MDR. In general, the relationship is stronger in the deep tropics and along the east coast. On average in these areas for every $1 \mathrm{~m} \mathrm{~s}^{-1}$ increase in mean intensity, mean intensification rates increase by $0.0083 \mathrm{~m} \mathrm{~s}^{-1} \mathrm{~h}^{-1}\left(0.39 \mathrm{kt} \mathrm{day}^{-1}\right)$.

The spatial relationship between local SST and intensification is also in agreement with Fraza and Elsner (2015). On average across the basin for every $1^{\circ} \mathrm{C}$ increase in local mean SST, mean intensification rates increase by $0.082 \mathrm{~m} \mathrm{~s}^{-1} \mathrm{~h}^{-1}$ $\left(3.83 \mathrm{kt} \mathrm{day}^{-1}\right)$. The values throughout the basin range from $0.078 \mathrm{~m} \mathrm{~s}^{-1} \mathrm{~h}^{-1}$ in the northeast to $0.084 \mathrm{~m} \mathrm{~s}^{-1} \mathrm{~h}^{-1}$ in the Gulf of Mexico.

As noted above, the main focus of this work is the relationship between intensification and climate factors. Here we consider the results from the model for three climate factors: ENSO, MJO, and NAO. The MEI is used as an index for ENSO. The peak of the posterior density for the
Table 1. DIC values for each iteration of the model runs. Intensity and SST are included in all iterations.

\begin{tabular}{lr}
\hline Climate covariates & DIC \\
\hline NAOI only & -70.42 \\
MEI only & -63.42 \\
MJOI only & -64.03 \\
NAOI \& MEI & -68.89 \\
NAOI \& MJOI & -70.16 \\
MEI \& MJOI & -66.75 \\
\hline
\end{tabular}

MEI coefficient (Fig. 10) is centered near zero with a mean of $0.0099 \mathrm{~m} \mathrm{~s}^{-1} \mathrm{~h}^{-1}$ per $1 \mathrm{SD}[-0.100,0.120](95 \% \mathrm{CI})$ $\left(0.46 \mathrm{kt} \mathrm{day}^{-1}\right)$ indicating ENSO does not have a significant effect on mean intensification rates at these spatial and temporal scales.

The MJOI is used as an index for the MJO. The posterior density on the MJOI coefficient (Fig. 10) is shifted to the right of zero indicating the $\mathrm{MJO}$ has a positive effect on mean intensification rates of $0.204 \mathrm{~m} \mathrm{~s}^{-1} \mathrm{~h}^{-1}$ per $1 \mathrm{SD}[-0.166$, $0.574]$ ( $95 \% \mathrm{CI})\left(9.52 \mathrm{kt} \mathrm{day}^{-1}\right)$ at these spatial and temporal scales.

The most significant factor on intensification rates is the NAO. The NAOI is used as an index for the NAO. The posterior density on the NAOI coefficient (Fig. 10) is shifted to the left of zero indicating the NAO has a negative effect on mean intensification rates with rates of $0.183 \mathrm{~m} \mathrm{~s}^{-1} \mathrm{~h}^{-1}$ per $1 \mathrm{SD}[-0.308,-0.0578](95 \% \mathrm{CI})\left(8.54 \mathrm{kt} \mathrm{day}^{-1}\right)$ at these spatial and temporal scales.

The significance of the NAOI in the model was tested by calculating the model output deviance information criterion (DIC) for model runs with different climate factors left out. A total of six model runs were done, and their DIC scores are listed in Table 1. The smallest DIC (indicating the best model fit) came when the NAOI was the only climate factor included.

\section{Intensification stratified by NAO years}

Here we take a closer look at the relationship between the $\mathrm{NAO}$ and hurricane intensification. We do this by comparing intensification rates for the 10 years with the highest NAOI in our study period to the intensification rates for the 10 years with the lowest NAOI. We take the five largest mean intensification rates from each of these 10 years; if fewer than five values are available for a particular year we take them all. The 10 most negative NAO years are 1975, 1977, 1978, 1979, 1980, 1985, 1987, 2001, 2010, and 2013. The 10 most positive NAO years are 1989, 1990, 1993, 1994, 1995, 1997, 2000, 2002, 2012, and 2014. This gives us 48 mean intensification values for the most negative years and 47 mean intensification values for the most positive years.

Adv. Stat. Clim. Meteorol. Oceanogr., 2, 105-114, 2016 


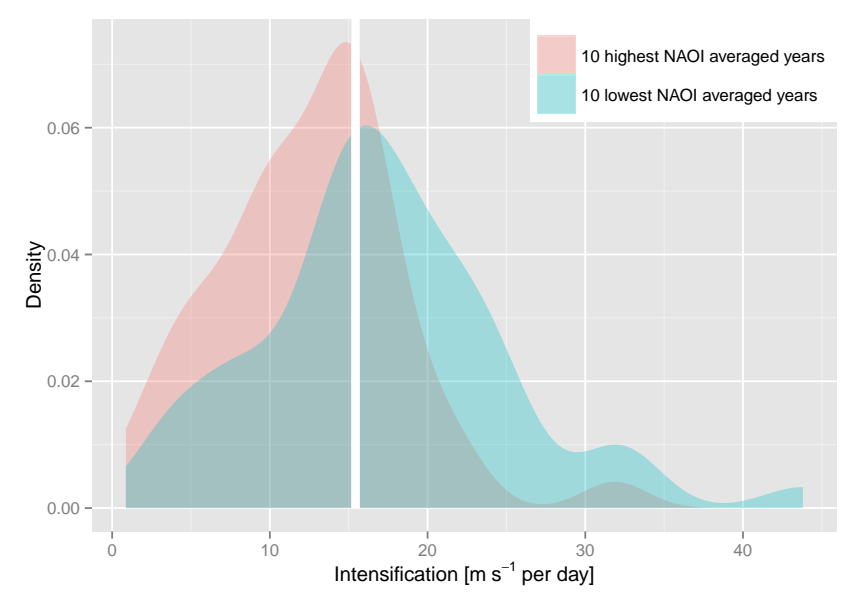

Figure 11. Density plot of five strongest mean intensification values (scaled to $24 \mathrm{~h}$ ) for each of the 10 highest NAOI years (pink) and for the 10 lowest NAOI years (blue) in units of $\mathrm{m} \mathrm{s}^{-1}$ day $^{-1}$ $\left(1 \mathrm{~m} \mathrm{~s}^{-1} \mathrm{day}^{-1}=1.944 \mathrm{kt} \mathrm{day}^{-1}\right)$. The white line is the RI threshold of $30 \mathrm{kt} \mathrm{day}^{-1}$.

The distribution of intensification for negative NAO years is different than the distribution of intensification for positive NAO years (Fig. 11). Here values of intensification are re-scaled to reflect $24 \mathrm{~h}$ intensification rates. The peaks are similarly situated near $15 \mathrm{~m} \mathrm{~s}^{-1}$ day $^{-1}$, which is close to the value of RI (white vertical line), but negative years feature more of the distribution above this value compared to positive years. In fact, $58 \%$ of the mean intensification rates for the negative NAOI years are greater than the RI rate, whereas only $34 \%$ of the mean intensification rates for the positive NAOI years are greater than the RI rate.

\section{Discussion}

Warmer seas and higher intensities are known to have a positive effect on intensification. Elsner et al. (2013) and Gray (1968) are just two of many studies to note that higher SSTs are beneficial to hurricanes. Elsberry et al. (2007) and Kaplan et al. (2010) noted that many of the strongest hurricanes in the North Atlantic basin underwent RI at some point during their lifetimes. Our results are in agreement with this research. Previous research has also shown that El Niño (positive MEI) reduces hurricane frequency across the North Atlantic basin (e.g., Arkin, 1982; Gray, 1984). However, our model shows that El Niño has no statistically significant effect on intensification when using MEI as an index. Further, the MJO has no statistically significant effect on intensification when using MJOI as an index.

The biggest revelation is that our model shows the NAO has a significant negative effect on intensification. There is no research concerning the NAO and intensification. However, previous research (e.g., Elsner, 2003; Xie et al., 2005) shows that a lower NAOI is associated with more hurricane activity in the North Atlantic basin. The physical explanation for this finding is unknown, but could be associated with the position of the North Atlantic subtropical high. Elsner et al. (2000) and Elsner et al. (2001) note that the North Atlantic subtropical high is weaker and positioned farther south and west than normal when the NAOI is negative. This favors storms tracking westward at a more southerly latitude over the warmer oceans. But our model includes SST so that is not the entire story. Weaker trade winds associated with a weaker NAO (Marshall et al., 2001) lead to less vertical wind shear and thus a better potential for intensification.

Finally, the finding that the distribution of hourly intensification rates scaled to $24 \mathrm{~h}$ peaks near the level of RI suggests that hourly intensification at the $24 \mathrm{~h}$ intensification rate is not exceptional, and has been hypothesized in some recent research (e.g., Kowch and Emanuel, 2015). Typical hourly intensification rates sustained over a day lead to a rare event. For instance, Kaplan and DeMaria (2003) define RI as approximately the top $5 \%$ of all $24 \mathrm{~h}$ intensification. From this, we can infer that rare RI events are the result of normal intensification rates but sustained for an unusually long period. This hints that understanding RI might improve by studying environmental conditions that allow sustained intensification rates.

\section{Summary}

Climatic effects on hurricane intensification rates are investigated for the North Atlantic basin. Hourly intensity and intensification rates are averaged on an $8^{\circ}$ latitude-longitude grid. The same grid is used to average seasonal values of SST. Indexes for the ENSO, MJO, and NAO are averaged by season. The distribution of annual mean intensification, mean intensity, and mean SST over the period 1975-2014 are mapped. Regions with the highest intensity and greatest intensification rates are co-located with regions of highest SSTs across the southern part of the basin and the southwestern Caribbean Sea.

A space-time statistical model is employed to quantify the relationships in a multivariate context. A full probability model is fit using the method of INLA. Posterior densities of model coefficients summarize the effect a variable has on intensification. Results show that intensity and SST have a positive effect on intensification consistent with previous research. That is, as intensity and SST increase so do hurricane intensification rates. Intensity had the strongest effect on intensification in the southern part of the basin and along the east coast. SST had the strongest effect in the southern part of the basin as well as in the Gulf of Mexico.

When climate factors are included in the model, we find that the NAO significantly affects intensification rates after controlling for intensity and SST. The peak density shows that for a $1 \mathrm{SD}$ decrease in the NAO, mean intensification increases by $0.183 \mathrm{~m} \mathrm{~s}^{-1} \mathrm{~h}^{-1}(0.36 \mathrm{kt})$. The reason for this 
effect is unknown, but it could be due to the position of the North Atlantic subtropical high and the strength of the trade winds. A combination of the high pressure center being further south and west along with weakened trade winds could allow for greater intensification rates. In contrast to the NAO, the ENSO has little effect on intensification rates after controlling for intensity and SST. This is likely because SST is already accounted for. Further, the MJO also has little effect on intensification rates as zero is within its $95 \%$ CI range.

One limitation of this study is the factors not included in the model. For example, the phase of the quasi-biennial oscillation (QBO) and the depth of the Saharan dust layer (Gray, 1990) might contribute to intensification, both of which are missing from the current model. Another limitation is the spatial scale used for the analysis and modeling. Although chosen with care to capture the salient features associated with climate influences on intensification, alternative scales are possible that could change the magnitude or significance of the results. Further research is needed to understand the physical role the NAO plays in modulating hurricane intensification. For example how does the NAO effect vary across the domain? Finally, do the same climate relationships hold in other hurricane basins?

\section{Data availability}

Atlantic hurricane dataset (HURDAT2) was downloaded from www.nhc.noaa.gov/pastall.shtml\#hurdat. SST data used in this study are from the NOAA Extended Reconstructed Sea Surface Temperature V3b (downloaded from http://www.esrl.noaa.gov/psd/data/ gridded/data.noaa.ersst.html\#detail). The analysis and modeling were performed using the open-source $\mathrm{R}$ package for statistical computing. The code and data used to produce the figures in this paper are available from https://github.com/erikf28/FrazaEtAlASCMO.

Acknowledgements. The authors would like to thank editor Chris Wikle and two anonymous reviewers for their helpful comments and suggestions.

Edited by: C. Wikle

Reviewed by: two anonymous referees

\section{References}

Arkin, P. A.: The relationship between interannual variability in the $200 \mathrm{mb}$ tropical wind field and the Southern Oscillation, Mon. Weather Rev., 110, 1393-1404, 1982.

Balling, R. C. J. and Cerveny, R. S.: Analysis of tropical cyclone intensification trends and variability in the North Atlantic Basin over the period 1970-2003, Meteorol. Atmos. Phys., 93, 45-51, doi:10.1007/s00703-006-0196-5, 2006.
Besag, J.: Statistical analysis of non-lattice data, Statistician, 179$195,1975$.

Blangiardo, M. and Cameletti, M.: Spatial and Spatio-temporal Bayesian Models with R-INLA, John Wiley \& Sons, 2015.

Cressie, N. and Wikle, C. K.: Statistics for spatio-temporal data, John Wiley \& Sons, 2011.

DeMaria, M., Kaplan, J., and Baik, J.-J.: Upper-level eddy angular momentum fluxes and tropical cyclone intensity change, J. Atmos. Sci., 50, 1133-1147, 1993.

Elsberry, R. L., Lambert, T. D. B., and Boothe, M. A.: Accuracy of Atlantic and Eastern North Pacific Tropical Cyclone Intensity Forecast Guidance, Weather Forecast., 22, 747-762, 2007.

Elsberry, R. L., Chen, L., Davidson, J., Rogers, R., Wang, Y., and $\mathrm{Wu}, \mathrm{L} .:$ Advances in understanding and forecasting rapidly changing phenomena in tropical cyclones, Tropical Cyclone Res. Rev., 2, 12 pp., 2013.

Elsner, J. B.: Tracking Hurricanes, B. Am. Meteorol. Soc., 84, 353 356, 2003.

Elsner, J. and Jagger, T.: Hurricane Climatology: A Modern Statistical Guide Using R, Oxford University Press, USA, 2013.

Elsner, J., Strazzo, S., Jagger, T., LaRow, T., and Zhao, M.: Sensitivity of Limiting Hurricane Intensity to SST in the Atlantic from Observations and GCMs, J. Climate, 26, 5949-5957, 2013.

Elsner, J., Jagger, T., and Niu, X.: Changes in the rates of North Atlantic major hurricane activity during the 20th century, Geophys. Res. Lett., 27, 1743-1746, doi:10.1029/2000GL011453, 2000.

Elsner, J. B., Bossak, B. H., and Niu, X.-F.: Secular changes to the ENSO-US hurricane relationship, Geophys. Res. Lett., 28, 41234126, 2001.

Fraza, E. and Elsner, J.: A Spatial Climatology of North Atlantic Hurricane Intensity Change, Int. J. Climatol., 34, 2918-2924, doi:10.1002/joc.3884, 2014.

Fraza, E. and Elsner, J. B.: A climatological study of the effect of sea-surface temperature on North Atlantic hurricane intensification, Phys. Geogr., 36, 395-407, 2015.

Gray, W. M.: Global view of the origin of tropical disturbances and storms, Mon. Weather Rev., 96, 669-700, 1968.

Gray, W.: Atlantic seasonal hurricane frequency, Part II: Forecasting its variability, Mon. Weather Rev., 112, 1669-1683, 1984.

Gray, W. M.: Strong association between West African rainfall and US landfall of intense hurricanes, Science, 249, 1251-1256, 1990.

Hijmans, R. J.: raster: Geographic data analysis and modeling, $\mathrm{R}$ package version 2.2-12, http://CRAN.R-project.org/package= raster, 2014.

Hodges, R. E., Jagger, T. H., and Elsner, J. B.: The sun-hurricane connection: Diagnosing the solar impacts on hurricane frequency over the North Atlantic basin using a space-time model, Nat. Hazards, 73, 1063-1084, 2014.

Jarvinen, B. R., Neumann, C. J., and Davis, M. A. S.: A tropical cyclone data tape for the North Atlantic basin, 1886-1983: Contents, limitations, and uses, Technical Memo. 22, NOAA NWS NHC, 1984.

Kaplan, J. and DeMaria, M.: Large-scale characteristics of rapidly intensifying tropical cyclones in the North Atlantic basin, Weather Forecast., 18, 1093-1108, 2003.

Kaplan, J., DeMaria, M., and Knaff, J. A.: A revised tropical cyclone rapid intensification index for the Atlantic and Eastern North Pacific basins, Weather Forecast., 25, 220-241, 2010. 
Klotzbach, P.: El Niño-Southern Oscillation, the MaddenJulian Oscillation and Atlantic basin tropical cyclone rapid intensification, J. Geophys. Res., 117, D14104, doi:10.1029/2012JD017714, 2012.

Klotzbach, P. J. and Oliver, E. C.: Modulation of Atlantic Basin Tropical Cyclone Activity by the Madden-Julian Oscillation (MJO) from 1905 to 2011, J. Climate, 28, 204-217, 2015.

Kowch, R. and Emanuel, K.: Are Special Processes at Work in the Rapid Intensification of Tropical Cyclones?, Mon. Weather Rev., 143, 878-882, 2015.

Law, K. T. and Hobgood, J. S.: A Statistical Model to Forecast Short-Term Atlantic Hurricane Intensity, Weather Forecast., 22, 967-980, 2007.

Madden, R. A. and Julian, P. R.: Description of global-scale circulation cells in the tropics with a 40-50 day period, J. Atmos. Sci., 29, 1109-1123, 1972.

Marshall, J., Kushnir, Y., Battisti, D., Chang, P., Czaja, A., Dickson, R., Hurrell, J., McCartney, M., Saravanan, R., and Visbeck, M.: North Atlantic climate variability: phenomena, impacts and mechanisms, Int. J. Climatol., 21, 1863-1898, 2001.
Martins, T. G., Simpson, D., Lindgren, F., and Rue, H.: Bayesian computing with INLA: new features, Comput. Stat. Data An., 67, 68-83, 2013.

NHC: Glossary of NHC Terms, http://www.nhc.noaa.gov/ aboutgloss.shtml, 2013.

Peduzzi, P., Chatenoux, B., Dao, H., De Bono, A., Herold, C., Kossin, J., Mouton, F., and Nordbeck, O.: Global trends in tropical cyclone risk, Nat. Clim. Change, 2, 289-294, 2012.

Pielke Jr., R. A., Gratz, J., Landsea, C. W., Collins, D., Saunders, M. A., and Musulin, R.: Normalized hurricane damage in the United States: 1900-2005, Nat. Hazards Rev., 9, 29-42, 2008.

Wallace, J. and Gutzler, D.: Teleconnections in the geopotential height field during the Northern Hemisphere winter, Mon. Weather Rev., 109, 784-812, 1981.

Wheeler, M. C. and Hendon, H. H.: An all-season real-time multivariate MJO index: Development of an index for monitoring and prediction, Mon. Weather Rev., 132, 1917-1932, 2004.

Xie, L., Yan, T., Pietrafesa, L. J., Morrison, J. M., and Karl, T.: Climatology and Interannual Variability of North Atlantic Hurricane Tracks., J. Climate, 18, 5370-5381, 2005. 